\title{
Impulsivity, gender, and the platelet serotonin transporter in healthy subjects
}

This article was published in the following Dove Press journal:

Neuropsychiatric Disease and Treatment

17 December 2009

Number of times this article has been viewed

\section{Donatella Marazziti \\ Stefano Baroni \\ Irene Masala \\ Francesca Golia \\ Giorgio Consoli \\ Gabriele Massimetti \\ Michela Picchetti \\ Mario Catena Dell'Osso \\ Gino Giannaccini \\ Laura Betti \\ Antonio Lucacchini \\ Antonio Ciapparelli}

Dipartimento di Psichiatria, Neurobiologia, Farmacologia e Biotecnologie, University of Pisa, Pisa, Italy
Correspondence: Donatella Marazziti

Dipartimento di Psichiatria, Neurobiologia, Farmacologia e Biotecnologie, University of Pisa, via Roma, 67, I-56I00 Pisa, Italy

$\mathrm{Tel}+39050835412$

Fax +390502158I

Emaildmarazzi@psico.med.unipi.it
Abstract: The present study explored the possible relationships between impulsivity, gender, and a peripheral serotonergic marker, the platelet serotonin (5-HT) transporter (SERT), in a group of 32 healthy subjects. The impulsivity was measured by means of the Barratt Impulsivity Scale, version 11 (BIS-11), a widely used self-report questionnaire, and the platelet SERT was evaluated by means of the specific binding of ${ }^{3} \mathrm{H}$-paroxetine $\left({ }^{3} \mathrm{H}-\mathrm{Par}\right)$ to platelet membranes, according to standardized protocols. The results showed that women had a higher BIS-11 total score than men, and also higher scores of two factors of the same scale: the motor impulsivity and the cognitive complexity. The analysis of the correlations revealed that the density of the SERT proteins, as measured by the maximum binding capacity $\left(\mathrm{B}_{\max }\right)$ of ${ }^{3} \mathrm{H}-\mathrm{Par}$, was significantly and positively related to the cognitive complexity factor, but only in men. Men showed also a significant and negative correlation with the dissociation constant, $\mathrm{Kd}$, of ( ${ }^{3} \mathrm{H}-\mathrm{Par}$ ) binding, and the motor impulsivity factor. These findings suggest that women are generally more impulsive than men, but that the 5-HT system is more involved in the impulsivity of men than in that of women.

Keywords: impulsivity, gender, serotonin transporter, Barratt Impulsivity Scale, platelets, ${ }^{3} \mathrm{H}$-paroxetine

\section{Introduction}

The brain serotonin (5-HT) system plays an important role in the modulation of different functions and behaviors including appetite, sleep, memory and learning, mood, sexuality. ${ }^{1,2}$ However, on the basis of a wealth of preclinical and clinical observations, ${ }^{3-8}$ one of the most intriguing suggestions regarding the general role of 5-HT in the central nervous system (CNS) is that it might serve as a "modulator" of impulsivity and aggression. ${ }^{9-13}$

Several studies, employing different means to reduce the functionality of 5-HT, generally led to increased aggressive behaviors in animal models. ${ }^{14,15}$ In humans, autopsies carried out on suicide cases revealed abnormalities of different serotonergic parameters, such as decreased 5-HT levels, ${ }^{16,17}$ increased and reduced density of 5-HT2A and 5-HT1A receptors, respectively. ${ }^{17,18}$ Furthermore, a localized reduction of the 5-HT transporter (SERT) binding in the ventral prefrontal cortex, or fewer SERT mRNA expressing neurons were detected in the dorsal raphe nuclei of suicide victims, as compared with individuals with other disorders. ${ }^{16,19,20}$

Reduced concentrations of 5-hydroxyindoleacetic acid (5-HIAA), the major metabolite of 5-HT, have been reported in the cerebrospinal fluid (CSF) of violent suicide attempters ${ }^{21,22}$ and especially in those who had committed it by violent means. ${ }^{23}$

submit your manuscript | www.dovepress.con 
The link between reduced CSF 5-HIAA and aggression has been subsequently supported by the observation of an inverse relationship with measures of impulsive aggression in male personality-disordered subjects, ${ }^{24,25}$ male violent offenders, ${ }^{3}$ or alcoholics. ${ }^{26,27}$ A similar relationship has been demonstrated between hormonal responses to acute serotonergic challenges and measures of impulsive aggression in personality-disordered subjects ${ }^{28-34}$ or healthy volunteers. $^{35-38}$

In spite of these intriguing suggestions, a direct evidence of a link between the serotonergic system and impulsivity is still lacking, especially in healthy subjects. This is also due to intrinsic problems of research on this topic: first, the definition of impulsivity, for which no general agreement exists. An exhaustive definition is that given by the International Society for Research on Impulsivity (ISRI), which considers it as "a human behavior without adequate thought, the tendency to act with less forethought than do most individuals of equal ability and knowledge, or a predisposition toward rapid, unplanned reactions to internal or external stimuli without regard to negative consequences of these reactions". Second, the assessment of impulsivity, which might permit to compare different studies. One of the most used and validated instruments is the socalled "Barratt Impulsivity Scale", which is the results of decades of efforts and modifications until the latest version 11 (BIS-11) ${ }^{39}$ and considers impulsivity as a trait influenced by temperament and, as such, heritable and widely distributed in the population. ${ }^{40,41}$ Third, the availability of peripheral models of the serotonergic system, which should be reliable, easy to obtain, relatively safe and to be applied routinely in large samples. The SERT present in platelets fulfills all these requirements, especially after the demonstration of its identity with the same structure expressed in the CNS. ${ }^{42,43}$ A reduced density of platelet SERT was reported in individuals with personality disorders and aggressive behavior and in suicide attempters. ${ }^{44,45}$ Others ${ }^{46}$ reported a relationship between the short variant of the SERT promoter polymorphism $\left(S L C 6 A 4^{*} C\right)$, a blunted fenfluramine-induced prolactin release and aggressive impulsivity, in a group of abstinent alcoholic patients and healthy volunteers, while suggesting that this genotype would contribute to altered serotonergic regulation of emotions. Previously, the same polymorphism was found to be linked to the two anxiety-related sub-dimensions of harm avoidance, ${ }^{47}$ and to increased neuroticism (which includes impulsivity) on a personality inventory and decreased agreeableness in general population samples. ${ }^{48,49}$

Given the paucity of available information, therefore, the aim of this study was to explore and compare impulsivity in a group of healthy individuals of both sexes, as well as to investigate the possible relationships between the platelet SERT and impulsivity characteristics. The platelet SERT was evaluated by means of the specific binding of ${ }^{3} \mathrm{H}$-paroxetine ( ${ }^{3} \mathrm{H}-\mathrm{Par}$ ), one of the most selective ligands to label it, and impulsivity was assessed by means of the BIS-11 questionnaire.

\section{Materials and methods Subjects}

Thirty-two drug-free volunteers of both sexes (15 men and 17 women, aged between 27 and 51 years, mean \pm standard deviation [SD]: $36 \pm 7$ ) were included in the study. They had no family or personal history of any major psychiatric disorder, as assessed by a psychiatric interview, carried out by a senior psychiatrist (DM) by means of the SCID. ${ }^{50}$ They were recruited amongst medical and nursing staff at the Dipartimento di Psichiatria, Neurobiologia, Farmacologia e Biotecnologie, University of Pisa, Italy. All subjects were free of any physical illness, as documented by a general check-up and by the normal blood and urine tests. All were psychotropic drug-free, none were heavy smokers or belonged to HIV-risk groups. They all gave their informed written consent to participate in the study, which was approved by the Ethics Committee of Pisa University.

\section{Impulsivity assessment}

The impulsivity was assessed by means of the BIS-11 questionnaire validated into Italian. ${ }^{51}$

The BIS-11 is a self-report scale developed to measure impulsivity as a stable characteristic, composed by 30 items, which are answered on a four-point scale; items are scored 1, 2, 3, 4 where 4 indicates the most impulsive response: the higher the total scores for all items, the higher the level of impulsivity. The total score ranges between 30 and 120, with no established cut-off point and is the result of the sum of three different subscales: attentional (rapid shifts of attention and impatience with complexity), motor (impetuous action), and nonplanning (lack of future orientation) impulsivity. In addition, the 30 items form six factors determined by principal component analyses: attention, motor impulsivity, self-control, cognitive complexity, perseverance, and cognitive instability.

\section{Preparation of platelet membranes and ${ }^{3} \mathrm{H}-\mathrm{Par}$ binding assay}

Twenty-five $\mathrm{ml}$ of blood was withdrawn from fasting subjects between 8:00 and 9:00 am in the months of January and February to avoid circadian or seasonal rhythms, into plastic 
tubes containing $5 \mathrm{~mL}$ of anticoagulant (sodium citrate, $2.2 \%$, and citric acid, 1.2\%). Platelet-rich plasma was obtained by low-speed centrifugation $\left(1,500 \mathrm{~g}\right.$ for $15 \mathrm{~min}$ at $\left.23^{\circ} \mathrm{C}\right)$. Platelets were precipitated from platelet-rich plasma by centrifugation at $1500 \mathrm{~g}$ for $15 \mathrm{~min}$ at $23^{\circ} \mathrm{C}$ and then stored at $-80^{\circ} \mathrm{C}$ until assay, which was performed within one week. At the time of assay, platelets were washed in $10 \mathrm{~mL}$ of ice-cold $50 \mathrm{mmol} / \mathrm{L}$ Tris-HCl buffer ( $\mathrm{pH} 7.4$ ) and were centrifuged at 10,000 $\mathrm{g}$ for $10 \mathrm{~min}$ at $4^{\circ} \mathrm{C}$. The resulting pellet was homogenized by an Ultraturrax homogenizer in 10 volumes of $5 \mathrm{mmol} / \mathrm{L}$ Tris- $\mathrm{HCl}$ buffer ( $\mathrm{pH}$ 7.4) and were centrifuged at 30,000 g for $10 \mathrm{~min}$ at $4^{\circ} \mathrm{C}$. The supernatant was discarded, and the final membrane pellet was re-suspended in the assay buffer $(50 \mathrm{mmol} / \mathrm{L}$ Tris- $\mathrm{HCl}, 120 \mathrm{mmol} / \mathrm{L} \mathrm{NaCl}$ and $5 \mathrm{mmol} / \mathrm{L} \mathrm{KCl}, \mathrm{pH} 7.4$ ), and homogenized by an Ultraturrax homogenizer. The binding of ${ }^{3} \mathrm{H}$-Par to SERT on platelet membranes was determined according to the method of Marazziti and colleagues. ${ }^{52}$ The ${ }^{3} \mathrm{H}$-Par binding assays were performed in an incubation mixture consisting of $100 \mu \mathrm{L}$ of platelet membranes (50-100 $\mu \mathrm{g}$ protein/tube), $50 \mu \mathrm{l}$ of ${ }^{3} \mathrm{H}$-Par (Perkin-Elmer, Life Science, Milan, Italy; specific activity: $15.5 \mathrm{Ci} / \mathrm{mmol}$ ) at concentrations ranging between 0.4 and $40 \mathrm{nmol} / \mathrm{L}$, and $1850 \mu \mathrm{L}$ of assay buffer. Specific binding was estimated as the binding remaining in the presence of $10 \mu \mathrm{mol} / \mathrm{L}$ fluoxetine (kindly provided by Eli-Lilly, Indianapolis, IN), used as the unlabeled competitor for SERT binding site. All samples were assayed in duplicate and incubated at $22^{\circ} \mathrm{C}$ for one hour. The reaction was then halted by adding $5 \mathrm{~mL}$ of cold assay buffer, followed by immediate filtration under vacuum through glass fiber filters GF/C (Whatman International, Maidstone, UK).
The filters were washed three times with $5 \mathrm{~mL}$ of the assay buffer and dried, and the SERT-bound radioactivity trapped on the filters was counted in $4 \mathrm{~mL}$ of scintillation fluid by a scintillation spectrometry counter 1600 TR (Packard Bioscience, Groningen, The Netherlands). Protein concentration was determined according to the method of Lowry, as modified by Peterson. ${ }^{53}$

\section{Statistical analyses}

Equilibrium-saturation binding data, the maximum binding capacity $\left(\mathrm{B}_{\max }, \mathrm{fmol} / \mathrm{mg}\right.$ protein $)$ and the dissociation constant $(\mathrm{Kd}, \mathrm{nM})$ were analyzed by means of iterative curve-fitting computer programmes EBDA [Biosoft, Cambridge, UK].

The differences in binding parameters or BIS total or subscale scores between women and men were analyzed by means of the Student's $t$-test.

The possible effects of age and sex on biological parameters were investigated by means of the analysis of covariance, while the correlations between variables were explored using the Pearson method, all with SPSS software (version 12.1; SPSS Inc, Chicago, IL, USA).

\section{Results}

The $\mathrm{B}_{\max }$ (mean $\pm \mathrm{SD}$, fmol/mg protein) and $\mathrm{Kd}$ (mean $\pm \mathrm{SD}$, $\mathrm{nM}$ ) values were $1135 \pm 119$ and $0.095 \pm 0.02$, with no difference between women and men (Table 1). The BIS total score in all subjects was $55.1 \pm 5.92$, significantly higher in women than in men $(58.76 \pm 6.9$ vs. $51.45 \pm 4.94$, $\mathrm{t}=-3.034, P=0.005)$. In addition, the following factor scores were also higher in women than in men: motor impulsivity

Table I ${ }^{3} \mathrm{H}$-Par binding parameters $\left(B_{\text {max }}\right.$, mean \pm SD, fmol/mg prot.; $\mathrm{Kd}$, mean $\left.\pm \mathrm{SD}, \mathrm{nM}\right)$ and $\mathrm{BIS}$ - I I total, subscale and factor scores (mean $\pm \mathrm{SD})$ in men and women

\begin{tabular}{|c|c|c|c|}
\hline & & Men & Women \\
\hline \multirow[t]{2}{*}{${ }^{3} \mathrm{H}$-Par binding parameters } & $\mathrm{B}_{\max }$ & $1135 \pm 127$ & $1137 \pm 111$ \\
\hline & $\mathrm{Kd}$ & $0.094 \pm 0.02$ & $0.096 \pm 0.03$ \\
\hline BIS-II total score & & $51.45 \pm 4.94$ & $58.76 \pm 6.9 *$ \\
\hline \multirow[t]{3}{*}{ BIS-II subscale } & Attentional & $18.36 \pm 2.87$ & $20.29 \pm 2.86$ \\
\hline & Motor & $17.18 \pm 1.72$ & $21.17 \pm 2.89$ \\
\hline & Nonplanning & $15.9 \pm 1.86$ & $17.29 \pm 3.78$ \\
\hline \multirow[t]{6}{*}{ BIS-II factor } & Attention & $7.09 \pm 1.3$ & $7.76 \pm 2.35$ \\
\hline & Motor impulsivity & $11.54 \pm 2.06$ & $14.7 \pm 3.05^{* *}$ \\
\hline & Self-control & $11.18 \pm 2.08$ & $12.58 \pm 3.1$ \\
\hline & Cognitive complexity & $11.27 \pm 1.79$ & $12.52 \pm 1.37^{* * *}$ \\
\hline & Perseverance & $5.63 \pm 1.12$ & $6.47 \pm 1.12$ \\
\hline & Cognitive instability & $4.72 \pm 1.27$ & $4.7 \pm 1.44$ \\
\hline
\end{tabular}

Notes: $*$ Significant: $\mathrm{t}=-3.034, P=0.005 ; * *$ significant: $\mathrm{t}=-3.004, P=0.006 ; * * *$ significant: $\mathrm{t}=-2.096, P=0.046$. 
A

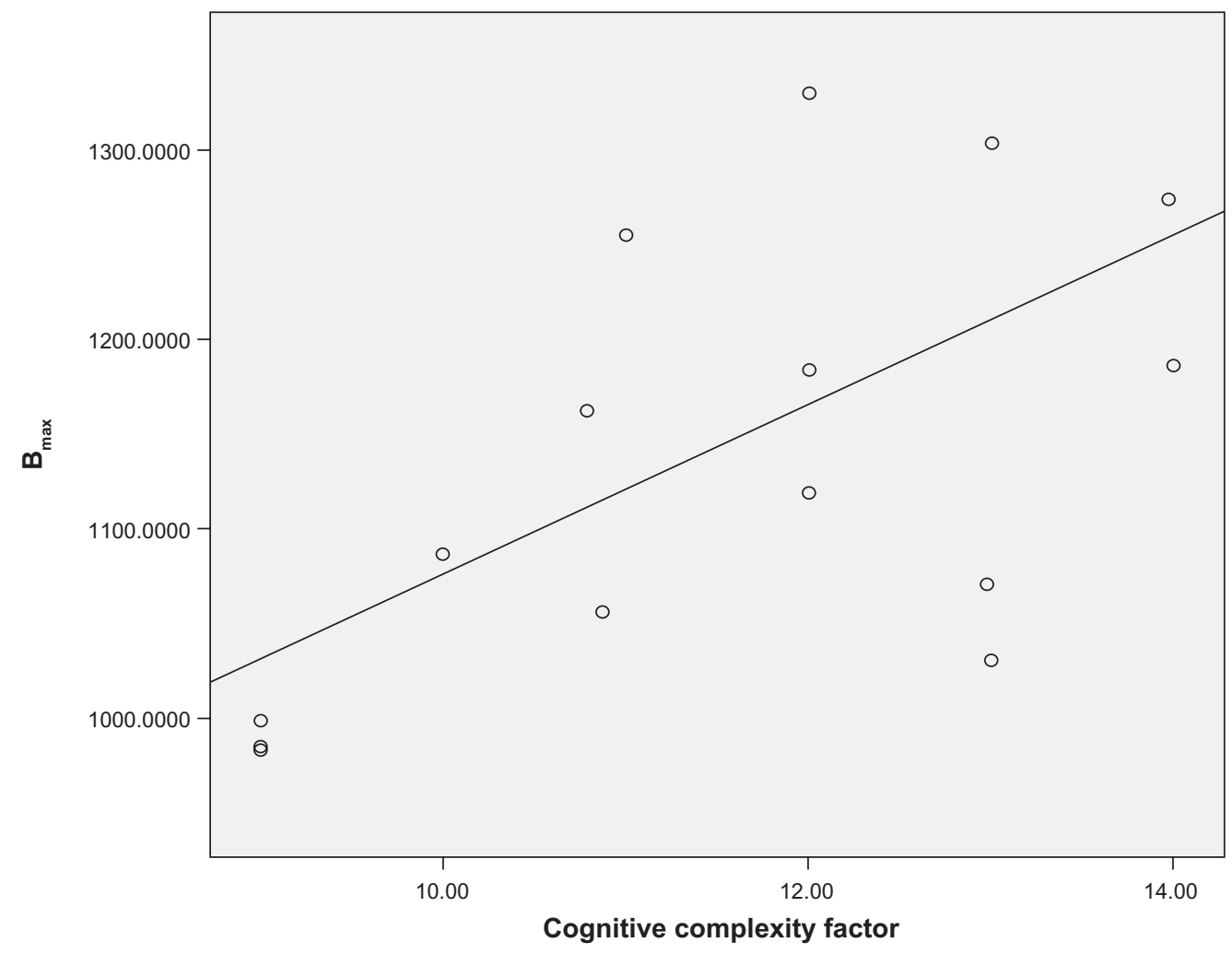

B

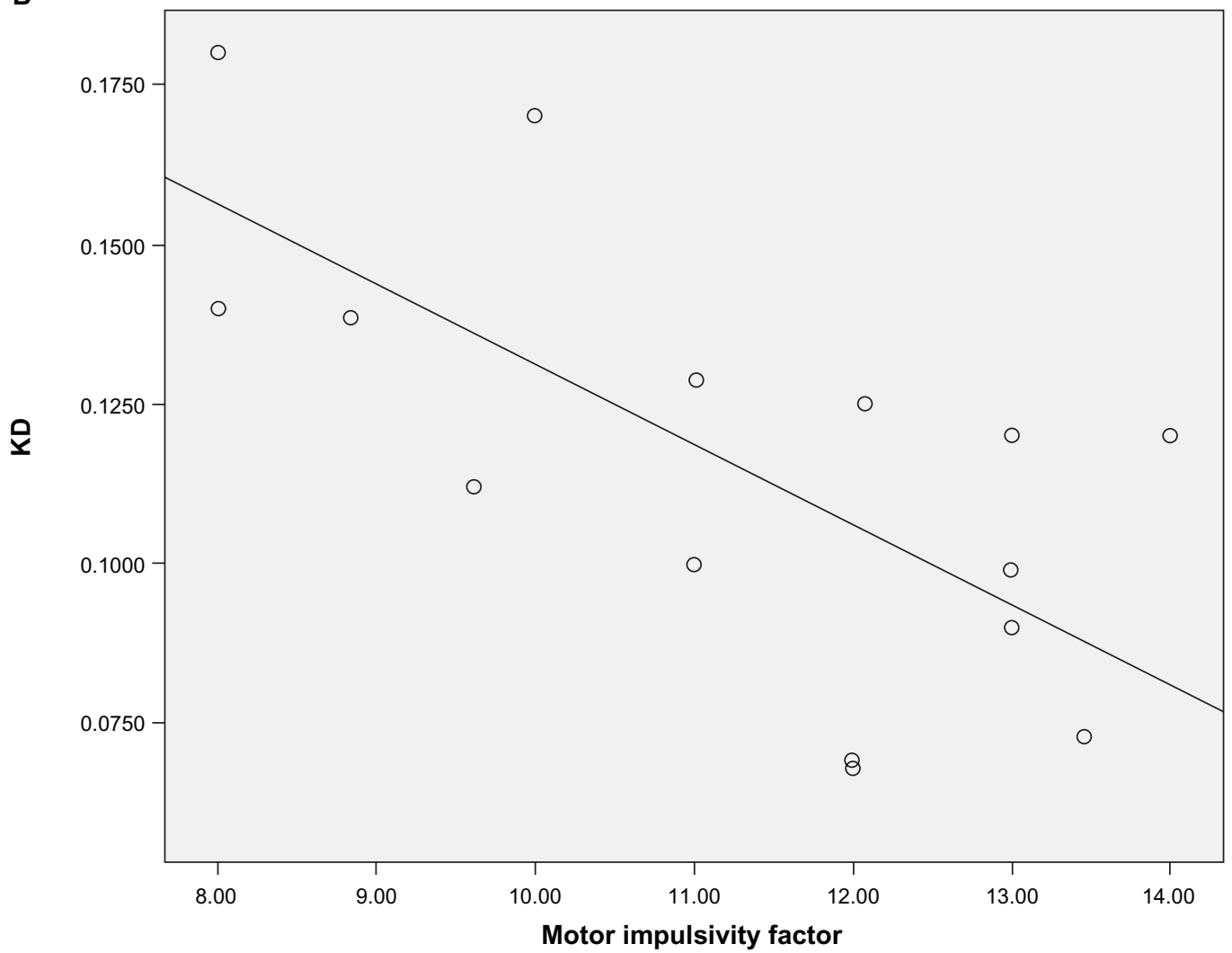

Figure I A) Positive correlation between the $B_{\max }$ and the cognitive complexity factor in men (Pearson correlation $=0.378, P=0.006$ ). B) Negative correlation between the $\mathrm{Kd}$ and the motor impulsivity factor in men (Pearson correlation $=-0.673, P=0.023$ ). 
$(\mathrm{t}=-3.004, P=0.006)$ and cognitive complexity $(\mathrm{t}=-2.096$, $P=0.046)$.

The correlation analysis showed that the $\mathrm{B}_{\max }$ was significantly and positively related to the cognitive complexity factor of the whole sample (Pearson correlation = $0.378, P=0.047$ ), however, when distinguishing between the two sexes, it emerged that it was present only in men (Pearson correlation $=0.628, P=0.039$ ), while it was lacking in women (Figure 1a). Men showed also a significant and negative correlation between the $\mathrm{Kd}$ and the motor impulsivity factor (Pearson correlation $=-0.673, P=0.023$ ) (Figure 1b).

\section{Discussion}

The present study explored and compared the possible differences in impulsivity characteristics, assessed by the BIS-11 questionnaire, in a group of healthy volunteers of both sexes, as well as the eventual correlations with the platelet SERT, evaluated by means of the ${ }^{3} \mathrm{H}-\mathrm{Par}$ binding parameters (the maximum binding capacity, $\mathrm{B}_{\max }$, and the dissociation constant, $\mathrm{Kd}$ ). Although the ensuing findings are affected by some limitations which should be acknowledged, such as the small sample size, the evidence that all subjects belonged to the same setting and had similar life-habits, and that impulsivity was assessed by a self-report scale only, factors that perhaps limit their generalizability, nevertheless they are intriguing. It should be noted, however, that rarely, both self-report and behavioral measures have been used together. ${ }^{54-56}$

First, the women of our sample showed a higher BIS-11 total score than men, and even the scores of two BIS-11 factors, the so-called "motor impulsivity" and "cognitive complexity", were higher in women than in men. These findings would indicate that women are generally more impulsive than men, at least when considering impulsivity as a trait, construct at the basis of the BIS questionnaire. Most of the literature data are in disagreement with our observations, as men and women do not appear to be consistently different on impulsivity, ${ }^{39,56,57}$ or men had higher scores at the BIS-11 questionnaire. ${ }^{58}$ In addition, gender has been shown to modulate the link between impulsivity and some health-risk behaviors, such as nicotine use in women, ${ }^{59,60}$ or alcohol intake in both men and women. ${ }^{58,59,61,62}$

Second, the correlation analysis revealed that the $\mathrm{B}_{\max }$ of ${ }^{3} \mathrm{H}$-Par binding, which is a measure of the number of the SERT proteins, was significantly and positively related to the BIS-11 cognitive complexity factor, but only in men. This means that the higher the density of the SERT proteins, the higher the score of the BIS- 11 factor. The men of our sample showed also another significant, albeit negative, cor- relation between the motor impulsivity factor and the $\mathrm{Kd}$, which is the inverse of the affinity constant, that is to say, when the $\mathrm{Kd}$ is low, the motor impulsivity increases, and viceversa. These findings are consistent with the results of a previous study reporting that increased platelet SERT affinity (low Kd) correlated with higher ratings of aggressive and externalising beahvior in childhood attention deficit/ hyperactivity disorder. ${ }^{63}$ In addition, they can be considered in agreement with the general observations of disturbances of the serotonergic system, as shown blunted prolactin response to fenfluramine amongst male, but not female subjects with borderline personality disorder, ${ }^{29,34,64-67}$ or lower prolactin or cortisol responses in healthy men, ${ }^{36-38,68,69}$ or increased platelet 5 -HT content in impulsive adolescents. ${ }^{70}$ Moreover, in impulsive men the blunted prolactin response has been related to the short variant of the SERT promoter ${ }^{46}$ while in impulsive girls such a variant seems to predispose to higher sensitivity to environmental adversity. ${ }^{71}$ Taken together, these findings suggest that 5-HT is more implicated in impulsivity in men than in women. Interestingly, it has been reported that acute tryptophan depletion increases impulsive response style in men only, without affecting mood. ${ }^{72,73}$ Therefore, it seems that gender is an important factor in the modulation of 5-HT upon impulsivity.

In conclusion, the findings of the present study would suggest that impulsivity is a complex phenomenon, with multiple facets, and resulting from the interplay of different factors, in particular the 5-HT system, whose role on this behavior is strongly modulated by gender, although with no doubt other neurotransmitters are involved..$^{13}$

Future studies should confirm or not our observations in larger sample of healthy subjects, as well as in patients with different impulse control disorders.

\section{Disclosures}

The authors report no conflicts of interest in this work.

\section{References}

1. Evenden JL. Varieties of impulsivity. Psychopharmacology. 1999;146:348-361.

2. Olivier B. Serotonin and aggression. Ann N Y Acad Sci. 2004;1036: 382-392.

3. Linnoila M, Virkkunen M, Scheinin M, Nuutile A, Rimon R, Goodwin FK. Low cerebrospinal-fluid 5-hydroxyindoleacetic acid concentration differentiates impulsive from non-impulsive violent behavior. Life Sci. 1983;33:2609-2614.

4. Vergnes M, Depaulis A, Boehrer A. Parachlorophenylalanine-induced serotonin depletion increases offensive but not defensive aggression in male rats. Physiol Behav. 1986;36:653-658.

5. Coccaro EF, Kavoussi RJ. Fluoxetine and impulsive aggressive behavior in personality-disordered subjects. Arch Gen Psychiatry. 1997;54:1081-1088. 
6. Harrison AA, Everitt BJ, Robbins TW. Central 5-HT depletion enhances impulsive responding without affecting the accuracy of attentional performance: interactions with dopaminergic mechanisms. Psychopharmacology. 1997;133:329-342.

7. Harrison AA, Everitt BJ, Robbins TW. Central serotonin depletion impairs both the acquisition and performance of a symmetrically reinforced go/no-go conditional visual discrimination. Behav Brain Res. 1999;100:99-112.

8. Fairbanks LA, Melega WP, Jorgensen MJ, Kaplan JR, McGuire MT. Social impulsivity inversely associated with CSF 5-HIAA and fluoxetine exposure in vervet monkeys. Neuropsychopharmacology. 2001;24: 370-378.

9. Soubrié P. Reconciling the role of central serotonin neurons in human and animal behavior. Behav Brain Sci. 1986;9:319-364.

10. Highley JD, Linnoila M. Low central nervous system serotonergic activity is trait like and correlates with impulsive behavior. Ann $N Y$ Acad Sci. 1997;836:39-56.

11. Kalenscher T, Ohmann T, Güntürkün $O$. The neuroscience of impulsive and self-controlled decisions. Int J Psychophysiol. 2006;62(2):203-211.

12. Serretti A, Mandelli L, Lorenzi C, et al. Temperament and character in mood disorders: influence of DRD4, SERTPR, TPH and MAO-A polymorphisms. Neuropsychobiology. 2006;53:9-16.

13. Pattij T, Vanderschuren LJ. The neuropharmacology of impulsive behaviour. Trends Pharmacol Sci. 2008;29(4):192-199.

14. Saudou F, Amara DA, Dierich A, et al. Enhanced aggressive behavior in mice lacking 5-HT1B receptor. Science. 1994;265(5180):1875-1878.

15. Stark KL, Oosting RS, Hen R. Inducible knockout strategies to probe the functions of 5-HT receptors. Ann N Y Acad Sci. 1998;861:57-66.

16. Korpi ER, Kleinman JE, Goodman SI, et al. Serotonin and 5-hydroxyindoleacetic acid in brains of suicide victims. Comparison in chronic schizophrenic patients with suicide as cause of death. Arch Gen Psychiatry. 1986;43(6):594-600.

17. Arango V, Underwood MD, Boldrini M, et al. Serotonin 1A receptors, serotonin transporter binding and serotonin transporter mRNA expression in the brainstem of depressed suicide victims. Neuropsychopharmacology. 2001;25(6):892-903.

18. Oquendo MA, Russo SA, Underwood MD, et al. Higher postmortem prefrontal 5-HT2A receptor binding correlates with lifetime aggression in suicide. Biol Psychiatry. 2006;59(3):235-243.

19. Mann JJ, Henteleff RA, Lagattuta TF, Perper JA, Li S, Arango V. Lower ${ }^{3} \mathrm{H}$-paroxetine binding in cerebral cortex of suicide victims is partly due to fewer high affinity, non-transporter sites. J Neural Transm. 1996;103(11):1337-1350.

20. Arango V, Underwood MD, Mann JJ. Serotonin brain circuits involved in major depression and suicide. Prog Brain Res. 2002;136:443-453.

21. Asberg M, Träskman L, Thorén P. 5-HIAA in the cerebrospinal fluid. A biochemical suicide predictor? Arch Gen Psychiatry. 1976;33(10):1193-1197.

22. Mann JJ, Malone KM. Cerebrospinal fluid amines and higherlethality suicide attempts in depressed inpatients. Biol Psychiatry. 1997;41(2):162-171.

23. Träskman-Bendz L, Asberg M, Schalling D. Serotonergic function and suicidal behavior in personality disorders. Ann N Y Acad Sci. 1986;487:168-174.

24. Brown GL, Goodwin FK, Ballenger JC, Goyer PF, Major LF. Aggression in humans correlates with cerebrospinal fluid amine metabolites. Psychiatry Res. 1979;1(2):131-139.

25. Brown GL, Ebert MH, Goyer PF, et al. Aggression, suicide, and serotonin: relationships to CSF amine metabolites. Am J Psychiatry. 1982;139(6):741-746

26. Limson R, Goldman D, Roy A, et al. Personality and cerebrospinal fluid monoamine metabolites in alcoholics and controls. Arch Gen Psychiatry. 1991;48(5):437-441.

27. Virkkunen M, Goldman D, Linnoila M. Serotonin in alcoholic violent offenders. Ciba Found Symp. 1996;194:168-182.

28. Coccaro EF, Siever LJ, Klar HM, et al. Serotonergic studies in patients with affective and personality disorders. Correlates with suicidal and impulsive aggressive behavior. Arch Gen Psychiatry. 1989;46(7):587-599.
29. Coccaro EF, Berman ME, Kavoussi RJ, Hauger RL. Relationship of prolactin response to d-fenfluramine to behavioral and questionnaire assessments of aggression in personality-disordered men. Biol Psychiatry. 1996;40(3):157-164.

30. Coccaro EF, Kavoussi RJ, Cooper TB, Hauger RL. Central serotonin activity and aggression: inverse relationship with prolactin response to d-fenfluramine, but not CSF 5-HIAA concentration, in human subjects. Am J Psychiatry. 1997;154(10):1430-1435.

31. Coccaro EF, Kavoussi RJ, Trestman RL, Gabriel SM, Cooper TB, Siever LJ. Serotonin function in human subjects: intercorrelations among central 5-HT indices and aggressiveness. Psychiatry Res. 1997;73(1-2):1-14.

32. Moss HB, Yao JK, Panzak GL. Serotonergic responsivity and behavioral dimensions in antisocial personalità disorder with substance abuse. Biol Psychiatry. 1990;28(4):325-338.

33. O'Keane V, Moloney E, O'Neill H, O'Connor A, Smith C, Dinan TG. Blunted prolactin responses to d-fenfluramine in sociopathy. Evidence for subsensitivity of central serotonergic function. $\mathrm{Br} J$ Psychiatry. 1992;160:643-646.

34. Soloff PH, Kelly TM, Strotmeyer SJ, Malone KM, Mann JJ. Impulsivity, gender, and response to fenfluramine challenge in borderline personality disorder. Psychiatry Res. 2003;119(1-2):11-24.

35. Cloninger CR, Przybeck TR, Svrakic DM, Wetzel RD. The Temperament and Character Inventory (TCI): A guide to its development and use. St. Luise, MO: Center for Psychobiology of Personality, Washington University; 1994.

36. Cleare AJ, Bond AJ. Does central serotonergic function correlate inversely with aggression? A study using D-fenfluramine in healthy subjects. Psychiatry Res. 1997;69(2-3):89-95.

37. Evans J, Platts H, Lightman S, Nutt D. Impulsiveness and the prolactin response to d-fenfluramine. Psychopharmacology (Berl). 2000;149(2):147-152.

38. Gerra G, Zaimovic A, Timpano M, Zambelli U, Delsignore R, Brambilla F. Neuroendocrine correlates of temperamental traits in humans. Psychoneuroendocrinology. 2000;25(5):479-496.

39. Patton JH, Stanford MS, Barratt ES. Factor structure of the Barratt impulsiveness scale. J Clin Psychol. 1995;51(6):768-774.

40. Coccaro EF, Bergeman CS, McClearn GE. Heritability of irritable impulsiveness: a study of twins reared together and apart. Psychiatry Res. 1993;48(3):229-242.

41. Livesley WJ, Jang KL, Vernon PA. Phenotypic and genetic structure of traits delineating personality disorder. Arch Gen Psychiatry. 1998;55(10):941-948.

42. Lesch KP, Wolozin BL, Murphy DL, Reiderer P. Primary structure of the human platelet serotonin uptake site: identity with the brain serotonin transporter. J Neurochem. 1993;60(6):2319-2322.

43. Qian Y, Melikian HE, Rye DB, Levey AI, Blakely RD. Identification and characterization of antidepressant-sensitive serotonin transporter proteins using site-specific antibodies. J Neurosci. 1995;15(2):1261-1274.

44. Coccaro EF, Kavoussi RJ, Sheline YI, Lish JD, Csernansky JG. Impulsive aggression in personality disorder correlates with tritiated paroxetine binding in the platelet. Arch Gen Psychiatry. 1996;53(6):531-536.

45. Marazziti D, Dell'Osso L, Rossi A, et al. Decreased platelet $\left[{ }^{3} \mathrm{H}\right]$ paroxetine binding sites in suicide attempters. Psychiatry Res. 2001;103(2-3):125-131.

46. Reist C, Mazzanti C, Vu R, Tran D, Goldman D. Serotonin transporter promoter polymorphism is associated with attenuated prolactin response to fenfluramine. Am J Med Genet. 2001;105(4):363-368.

47. Mazzanti CM, Lappalainen J, Long JC, et al. Role of the serotonin transporter promoter polymorphism in anxiety-related traits. Arch Gen Psychiatry. 1998;55(10):936-940.

48. Lesch KP, Bengel D, Heils A, et al. Association of anxiety-related traits with a polymorphism in the serotonin transporter gene regulatory region. Science. 1996;274(5292):1527-1531.

49. Greenberg BD, Li Q, Lucas FR, et al. Association between the serotonin transporter promoter polymorphism and personality traits in a primarily female population sample. Am J Med Genet. 2000;96(2): 202-216. 
50. First MB, Spitzer RL, Gibbon M, Williams JBW. Structured Clinical Interview for DSM-IV Axis I Disorders-Patient Edition (SCID-I P, Version 2.0, 497 revision). New York, NY: Biometrics Research, New York State Psychiatric Institute; 1997.

51. Fossati A, Di Ceglie A, Acquarini E, Barratt ES. Psychometric properties of an Italian version of the Barratt Impulsiveness Scale-11 (BIS-11) in nonclinical subjects. J Clin Psychol. 2001;57(6):815-828.

52. Marazziti D, Rossi A, Gemignani A, et al. Decreased platelet ${ }^{3} \mathrm{H}$-paroxetine binding in obsessive-compulsive patients. Neuropsychobiology. 1996;34:184-187.

53. Peterson GL. A simplification of the protein assay method of Lowry et al which is more generally applicable. Anal Biochem. 1977;83:356-366.

54. White JL, Moffitt TE, Caspi A, Bartusch DJ, Needles DJ, StouthamerLoeber M. Measuring impulsivity and examining its relationship to delinquency. J Abnorm Psychol. 1994;103(2):192-205.

55. Lane S, Cherek DR, Rhodes HM, Pietras CJ, Techeremissine OV. Relationships among laboratory and psychometric measures of impulsivity: implications in substance abuse and dependence. Addict Disord Their Treat. 2003;2:33-40.

56. Reynolds B, Ortengren A, Richards JB, de Wit H. Dimensions of impulsive behaviour: personality and behavioural measures. Pers Indiv Dif. 2006;40:305-315.

57. Feingold A. Gender differences in personality: a meta-analysis. Psychol Bull. 1994;116(3):429-456.

58. Stoltenberg SF, Batien BD, Birgenheir DG. Does gender moderate associations among impulsivity and health-risk behaviors? Addict Behav. 2008;33(2):252-265.

59. Waldeck TL, Miller LS. Gender and impulsivity differences in licit substance use. J Subst Abuse. 1997;9:269-275.

60. Granö N, Keltikangas-Järvinen L, Kouvonen A, et al. Impulsivity as a predictor of newly diagnosed depression. Scand J Psychol. 2007;48(2):173-179.

61. Caspi A, Begg D, Dickson N, et al. Personality differences predict health-risk behaviors in young adulthood: evidence from a longitudinal study. J Pers Soc Psychol. 1997;73(5):1052-1063.

62. Gerald MS, Higley JD. Evolutionary underpinnings of excessive alcohol consumption. Addiction. 2002;97(4):415-425.

63. Oades RD, Slusarek M, Velling S, Bondy B. Serotonin platelettransporter measures in childhood attention-deficit/hyperactivity disorder (ADHD): clinical versus experimental measures of impulsivity. World J Biol Psychiatry. 2002;3(2):96-100.
64. Hollander E, Stein DJ, DeCaria CM, et al. Serotonergic sensitivity in borderline personality disorder: preliminary findings. Am J Psychiatry. 1994;151(2):277-280.

65. Stein DJ, Hollander E, DeCaria CM, Simeon D, Cohen L, Aronowitz B. $\mathrm{m}$-Chlorophenylpiperazine challenge in borderline personality disorder: relationship of neuroendocrine response, behavioral response, and clinical measures. Biol Psychiatry. 1996;40(6):508-513.

66. Martial J, Paris J, Leyton M, et al. Neuroendocrine study of serotonin function in female borderline personalità disorder patients: a pilot study. Biol Psychiatry. 1997;42(8):737-739.

67. New AS, Trestman RL, Mitropoulou V, et al. Serotonergic function and self-injurious behavior in personality disorder patients. Psychiatry Res. 1997;69(1):17-26.

68. Ruegg RG, Gilmore J, Ekstrom RD, et al. Clomipramine challenge responses covary with Tridimensional Personality Questionnaire scores in healthy subjects. Biol Psychiatry. 1997;42(12):1123-1129.

69. Manuck SB, Flory JD, McCaffery JM, Matthews KA, Mann JJ, Muldoon MF. Aggression, impulsivity, and central nervous system serotonergic responsivity in a nonpatient sample. Neuropsychopharmacology. 1998;19(4):287-299.

70. Askenazy F, Caci H, Myquel M, Darcourt G, Lecrubier Y. Relationship between impulsivity and platelet serotonin content in adolescents. Psychiatry Res. 2000;94(1):19-28.

71. Paaver M, Kurrikoff T, Nordquist N, Oreland L, Harro J. The effect of 5-HTT gene promoter polymorphism on impulsivity depends on family relations in girls. Prog Neuropsychopharmacol Biol Psychiatry. 2008;32(5):1263-1268.

72. Walderhaug E, Lunde H, Nordvik JE, Landrø NI, Refsum H, Magnusson A. Lowering of serotonin by rapid tryptophan depletion increases impulsiveness in normal individuals. Psychopharmacology (Berl). 2002;164(4):385-391.

73. Walderhaug E, Magnusson A, Neumeister A, et al. Interactive effects of sex and 5-HTTLPR on mood and impulsivity during tryptophan depletion in healthy people. Biol Psychiatry. 2007;62(6):593-599.
Neuropsychiatric Disease and Treatment

\section{Publish your work in this journal}

Neuropsychiatric Disease and Treatment is an international, peerreviewed journal of clinical therapeutics and pharmacology focusing on concise rapid reporting of clinical or pre-clinical studies on a range of neuropsychiatric and neurological disorders. This journal is indexed on PubMed Central, the 'PsycINFO' database and CAS, and is the official

\section{Dovepress}

journal of The International Neuropsychiatric Association (INA). The manuscript management system is completely online and includes a very quick and fair peer-review system, which is all easy to use. Visit http://www.dovepress.com/testimonials.php to read real quotes from published authors. 